\title{
SERUM TRANSAMINASES AND ISOCITRIC DEHYDROGENASE IN KWASHIORKOR
}

\author{
BY \\ D. N. BARON \\ From the Department of Chemical Pathology, Royal Free Hospital and School of Medicine, \\ London, and University College Hospital, Ibadan, Nigeria
}

(RECEIVED FOR PUBLICATION NOVEMBER 18, 1959)

Serum glutamic oxalacetic transaminase (G-OT), glutamic-pyruvic transaminase (G-PT), and isocitric dehydrogenase (ICD) have been estimated in six groups of subjects, namely, normal British adults, normal Nigerian adults, undernourished Nigerian adults and children, Nigerian children with florid protein malnutrition (kwashiorkor), and cases of protein malnutrition after treatment.

The normal range in Nigerian adults was apparently slightly lower than in European adults.

A marked increase in serum enzyme activity was found in florid malnutrition, and a slight rise in undernutrition. In all cases serum G-PT showed lesser changes than G-OT and ICD.

The causes of these abnormalities are discussed. The increased serum enzyme activity is thought to be derived primarily from the liver and possibly also from voluntary muscle. Estimation of serum enzymes is recommended in the investigation of protein malnutrition.

In West Africa protein malnutrition presents in children as kwashiorkor. Amongst the established pathological findings in kwashiorkor are fatty liver and muscle wasting.

Determination of the activities in serum of enzymes which take part in cellular metabolic processes provides tests of cellular damage, particularly in the liver, which are more sensitive than any other laboratory procedures. This damage may be altered selective permeability, and does not necessarily imply necrosis. It was thought that these serum estimations, in particular of glutamic-oxalacetic transaminase (G-OT), glutamic-pyruvic transaminase (G-PT), and isocitric dehydrogenase (ICD), might detect hepatocellular damage in cases of protein malnutrition before other biochemical or clinical signs of liver involvement could be found. During a visit to the Chemical Pathology Department of University College Hospital, Ibadan, Nigeria, in the autumn of 1958 this problem was investigated, and an attempt was made to correlate the results with the general biochemical survey of kwashiorkor proceeding in that department.

\section{Clinical Material}

(A) European Controls (22 Subjects). - They were normal subjects, in the same age group as the Nigerian normals, who had previously been studied at the Royal Free Hospital.
(B) Normal Adults (14 Subjects).-They were healthy Nigerian medical students, aged 20-30 years. They came from all parts of the country and were eating a mixed diet which contained about $70 \mathrm{~g}$. protein daily. No normal children were examined in this series.

(C/D) Undernourished Adults (Seven Subjects) and Children (10 Subjects). - They were living in an agricultural village (Ilora) about 10 miles from Ibadan, which was undergoing a nutritional survey, and I am grateful to Dr. Alexander Boyo for his collaboration. The adults were aged $25-40$ and the children 5-7. They had no evidence of illness and were living a normal life; they were not anaemic and had normal serum protein levels. The daily protein intake of the adults was about $40 \mathrm{~g}$.: that of the children is not known, but was probably less.

(E) Children with Protein Undernutrition (Kwashiorkor) (11 Subjects). - They were in-patients or out-patients of University College Hospital, Ibadan, with a history of a very low protein diet, who had clinical symptoms of kwashiorkor of various grades of severity, and a total serum protein of less than $5 \mathrm{~g}$. $/ 100 \mathrm{ml}$. The age distribution was 1-6 years, and they were in general a few years younger than the undernourished children.

(F) Children with Recovered Protein Undernutrition (Nine Subjects).-They were out-patients of University College Hospital, Ibadan, who had recently finished their course of treatment for kwashiorkor (a high-protein diet), were clinically recovered, and their total serum protein was more than $6.5 \mathrm{~g} . / 100 \mathrm{ml}$. 


\section{Methods}

Serum G-OT was measured by the method of Karmen (1955), serum G-PT by the method of Wróblewski and LaDue (1956), serum ICD by the method of Wolfson and Williams-Ashman (1957), all with minor modifications, e.g., most analyses were performed with $0.2 \mathrm{ml}$. serum. The question of units is important (Daly and Jordan, 1959). It is possible to express results of serum enzyme analyses either in spectrophotometric units (for G-OT, Karmen, 1955 ; for G-PT, Wróblewski and LaDue, 1956 ; for ICD, Kerppola, Nikkilä, and Pitkänen, 1959), or in substrate units (for G-OT, Hauss and Leppelmann, 1958 ; for G-PT, Dreyfus, Schapira, and Schapira, 1958; for ICD, Wolfson and Williams-Ashman, 1957). Spectrophotometric units are easier to calculate, as a simple factor of the change in optical density which occurs during the estimation, provided that conditions are standard. They have been almost universally used for G-OT and G-PT. Substrate units, which represent quantities of reactant used or formed, are enzymologically more correct and are perhaps more commonly used for ICD. The optimum temperature to which results should be corrected is also undecided (Baron and Bell, 1959a). In this work spectrophotometric units, one unit being 0.001 change in $\mathrm{O} . \mathrm{D}_{340} / \mathrm{ml}$. serum in $3 \mathrm{ml}$. reaction volume/ minute at $25^{\circ} \mathrm{C}$. (as this was the temperature of the air-conditioned laboratory), were employed for all three enzymes ; for ICD, 1 spectrophotometric unit = 30 reactant units. ${ }^{*}$

In the routine chemical pathology laboratory, serum proteins were estimated by the method of Wolfson, Cohn, Calvary, and Ichiba (1948), serum bilirubin by the method of Powell (1944), and serum cholesterol by the method of Sperry and Webb (1950). The normals for Nigerian children are: total protein 6$8.5 \mathrm{~g} . / 100 \mathrm{ml}$., albumin $2.5-4.0 \mathrm{~g} . / 100 \mathrm{ml}$., bilirubin 0.3-1.0 mg./100 ml., total cholesterol $100-180 \mathrm{mg}$./ $100 \mathrm{ml}$., percentage free cholesterol $20-40 \%$ (Edozien, personal communication).

\footnotetext{
${ }^{*}$ In a previous communication (Baron and Bell, 1959b), ICD units were expressed per ml. serum $/ 1.5 \mathrm{ml}$. reaction volume: this unit introduces confusion and has been abandoned. A recent international subcommission has recommended that all enzyme units be expressed as millimole substrate utilized /minute/unit volume (? $\mathrm{ml}$. or 1., King, E. J., personal communication).
}

\section{Results}

In the transaminase assays I observed rapid utilization of D.P.N.H. before the addition of oxoglutarate in the analysis of certain sera from children of groups C, D, and E. This was not found in the sera of adults, and was not apparently related to any other biochemical finding. It was considered that a high concentration of plasma

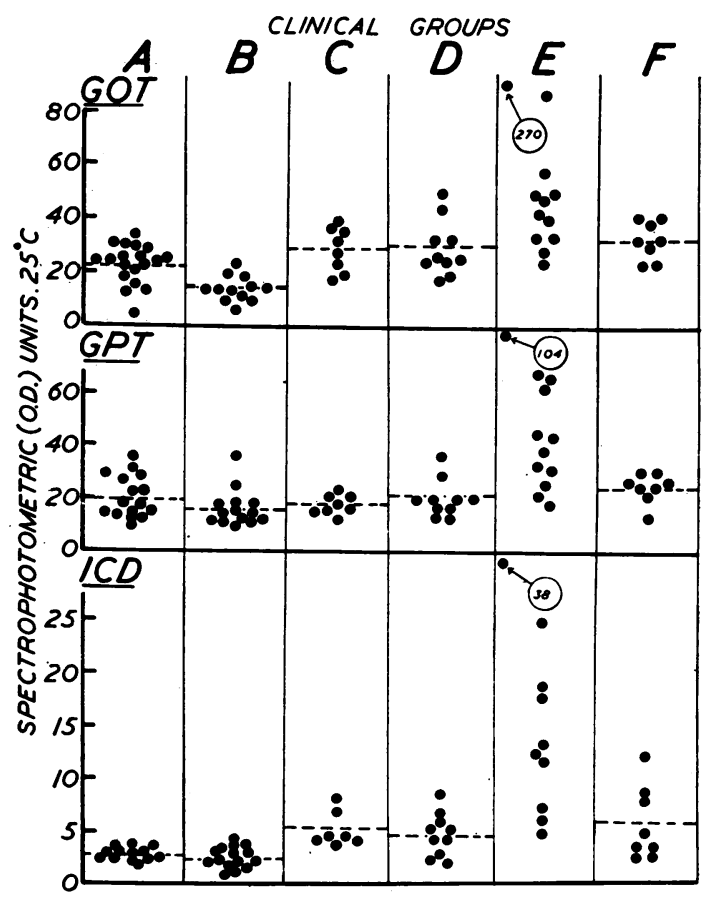

FIG. 1.-Chart showing results of serum G-OT. G-PT, and ICD analyses in six clinical groups. (A) Normal European adults, (B) normal Nigerian adults, (C) undernourished Nigerian adults, (D) undernourished Nigerian children, (E) active kwashiorkor, (F) recovered kwashiorkor. (The means are expressed in all groups except $\mathrm{E}$ by horizontal dashes.)

TABLE I

SERUM ENZYME ACTIVITIES AND RESULTS OF OTHER SERUM ANALYSES IN CHILDREN WITH PROTEIN MALNUTRITION (KWASHIORKOR)

\begin{tabular}{|c|c|c|c|c|c|c|c|c|}
\hline Case No. & $\underset{(\mathrm{g} . / 100 \mathrm{ml} .)}{\text { Albumin }}$ & $\begin{array}{c}\text { Total } \\
\text { Protein } \\
(\mathrm{g} . / 100 \mathrm{ml} .)\end{array}$ & $\underset{\text { (units/ml.) }}{\text { G-OT }}$ & $\underset{\text { (units } / \mathrm{ml} \text {.) }}{\text { G-PT }}$ & $\underset{\text { (units/ml.) }}{\text { ICD }}$ & $\begin{array}{c}\text { Total } \\
\text { Bilirubin } \\
\text { (mg./100 ml.) }\end{array}$ & $\begin{array}{c}\text { Total } \\
\text { Cholesterol } \\
(\mathrm{mg} \cdot / 100 \mathrm{ml} .)\end{array}$ & $\begin{array}{c}\% \\
\text { Free } \\
\text { Cholesterol }\end{array}$ \\
\hline $\begin{array}{lr}M & 22 \\
M & 7 \\
M & 17 \\
M & 15 \\
M & 8 \\
M & 13 \\
M & 11 \\
M & 6 \\
M & 3 \\
M & 25 \\
M & 5 \\
M & 16\end{array}$ & $\begin{array}{l}0.4 \\
0.4 \\
0.9 \\
0.9 \\
0.9 \\
0.9 \\
1.3 \\
1.4 \\
1.4 \\
1.8 \\
1.8 \\
2.0\end{array}$ & $\begin{array}{l}3 \cdot 4 \\
4 \cdot 2 \\
3 \cdot 9 \\
4 \cdot 0 \\
4 \cdot 4 \\
4 \cdot 8 \\
3 \cdot 9 \\
4 \cdot 6 \\
4 \cdot 8 \\
3 \cdot 8 \\
5 \cdot 0 \\
3 \cdot 9\end{array}$ & $\begin{array}{r}58 \\
43 \\
27 \\
49 \\
35 \\
94 \\
270 \\
24 \\
35 \\
49 \\
46 \\
40\end{array}$ & $\begin{array}{r}66 \\
20 \\
45 \\
21 \\
44 \\
33 \\
104 \\
62 \\
65 \\
31 \\
26 \\
39\end{array}$ & $\begin{array}{r}12 \\
5 \\
5 \\
6 \\
25 \\
18 \\
38 \\
7 \\
19 \\
12 \\
14\end{array}$ & $\begin{array}{l}0.6 \\
0.6 \\
3.0 \\
0.6 \\
\overline{0.3} \\
\frac{1.8}{\overline{0.6}} \\
1.2 \\
\overline{0.6}\end{array}$ & $\begin{array}{l}\frac{265}{E} \\
\overline{171} \\
\frac{305}{\overline{-}} \\
\frac{240}{230} \\
-\end{array}$ & $\begin{array}{l}\frac{40}{-} \\
\frac{67}{67} \\
\frac{90}{60} \\
\frac{50}{-}\end{array}$ \\
\hline
\end{tabular}


pyruvate could at least in part account for this finding, but because of lack of time I was not able to investigate this further. This has been confirmed by later work (Edozien, 1959).

Fig. 1 is a comparison of the results of the serum enzyme estimations on all groups of subjects. The diagram shows, as well as the scatter, the mean for all groups except $E$ where the considerable scatter would make it irrelevant. The small numbers involved, and the asymmetric grouping, make statistical analysis unwise. However, inspection of the results yields useful information.

Normal Europeans (A) seem to have slightly higher values for the three serum enzymes in comparison with normal Nigerians (B). It is doubtful whether any significance can be attached to this, but-it would be interesting if this observation were confirmed on larger numbers. If so, it would not be the only biochemical parameter to be different in healthy west Africans and healthy west Europeans (Edozien, 1958): for example, which may be relevant, serum albumin is lower in Nigerians than in Europeans.

The undernourished adults (C) have serum enzyme activities that are generally moderately increased, but the increase in G-PT is small. The increase in G-OT and ICD is more apparent, and the mean values are about twice those found in normal subjects. The values found in undernourished children (D) are similar to those of the undernourished adults.

In children with established protein malnutrition (E) a marked increase in serum enzyme activity (over D) is usually found. Again G-PT shows the smallest changes, and some results are not increased. The proportionate increase of ICD activity is probably greater than of G-OT activity. Table I gives the results of the serum enzyme estimations compared with results of other biochemical analyses in this group. The cases are arranged in order of the serum albumin concentration, which serves as an arbitrary index of the degree of malnutrition. There is no apparent correlation between the enzyme activities and any other biochemical abnormalities. The subject (M 11) with the most abnormal enzymes results did have the most abnormal cholesterol and was jaundiced but did not have the grossest hypoproteinuria, whereas M 17, who was severely jaundiced, had very little change in serum enzymes.

In the cured children ( $F)$ the serum enzyme activities show similar values to those found in the undernourished children (D) of their own home environment.

\section{Discussion}

In protein malnutrition two opposing factors could affect serum enzyme activities. As enzymes are proteins, the general protein deficiency could also affect the synthesis of the serum enzymes; low values for serum alkaline phosphatase, correlating with low serum albumin, have been reported in kwashiorkor (Schwartz, 1956). On the other hand, tissue wasting and cell damage could increase the serum concentrations of the intracellular enzymes. The increase in serum enzymes found in kwashiorkor could come from erythrocytes, cardiac muscle, voluntary muscle, or liver.

Haemolysis causes an increase in serum ICD, but very little in G-OT or G-PT. Care was taken in collecting and separating the blood, and any haemolysed samples were rejected.

It is established that in myocardial necrosis, when the serum G-OT is high, the G-PT is normal or slightly raised (Wróblewski, 1958) and the ICD is also normal (Baron and Bell, 1959b). The abnormal enzyme pattern of myocardial damage is quite different from that found here in protein malnutrition.

Wasting of voluntary muscle is marked in kwashiorkor. Although muscle wasting in starvation is not associated with a rise in serum aldolase or lactic dehydrogenase (White, 1958), yet these enzymes, G-OT, and to a lesser extent G-PT, show increased serum activity in muscle disease (Dreyfus, Schapira, and Schapira, 1958). The concentration of ICD in voluntary muscle is low, and in muscular dystrophy, where other serum enzymes are markedly raised, serum ICD is normal (White, 1958). In a small personal series of cases of muscle dystrophy and myopathy, with raised serum G-OT, the serum ICD was normal (Baron and Bell, unpublished observations). This evidence suggests that skeletal muscle damage is not the principal cause of the rise in serum enzymes in kwashiorkor.

The abnormal enzyme pattern in this series is the same as that found in hepatocellular damage in which serum ICD, G-OT, and G-PT are all increased, though there may be variations in the proportionate increases in the different enzymes in different types of liver disease (Sterkel, Spencer, Wolfson, and Williams-Ashman, 1958 ; Wróblewski, 1958 ; Kerppola et al., 1959). The evidence supports the view that the alterations in serum enzymes in protein malnutrition are due primarily to release of enzymes from liver cells, though general tissue breakdown, principally in the skeletal muscles, may play a part. 
As different "liver function tests" measure different functions of the liver, the lack of correlation between the abnormal enzyme results and the results of the other liver function tests is not surprising, and occurs in other liver diseases. In patients with kwashiorkor dying at the height of the illness the main structural change in the liver is deposition of fat, which is more marked than cell necrosis. In chlorpromazine jaundice there is an increase in serum G-OT without apparent liver cell necrosis, and it has been suggested that this is caused by altered cell permeability (Shay and Siplet, 1957): the same may apply in kwashiorkor. In their studies in Guatemala on the biochemical changes in the liver of kwashiorkor, Burch, Arroyave, Schwartz, Padilla, Béhar, Viteri, and Scrimshaw (1957) showed that an average of $30 \%$ of liver protein was lost, and that (of the enzymes studied here) the concentration of G-OT relative to protein was unchanged: their results indicate that liver G-OT is lost in parallel with liver protein.

As a result of the studies it is suggested that estimation of serum enzymes may be a useful additional tool in the assessment of cases of incipient or florid protein malnutrition. Serum G-OT is at present the recommended enzyme to assay, as the changes are almost as consistent as in serum ICD, but a simple and relatively cheap colorimetric method of assay is available. Colorimetric assay of ICD (Bell and Baron, 1959) requires the relatively expensive TPN.

This work is being continued, in collaboration, by Dr. J. C. Edozien at Ibadan, with special reference to serial observations and correlation of these serum enzyme changes with other abnormalities.

I am very grateful to the Council of the Royal Free Hospital School of Medicine and the Council of University College, Ibadan, for making possible my visit to Ibadan. I am greatly indebted to Dr. J. C. Edozien for granting me the hospitality of his department and for his help and criticism throughout this work. I wish to thank his staff for their collaboration, the clinical staff at Ibadan for allowing me to examine specimens from their patients, and Mrs. Joyce L. Bell, Ph.D., for much biochemical advice.

\section{REFERENCES}

Baron, D. N., and Bell, J. L. (1959a). Lancet, 1, 367. (1959b). J. clin. Path., 12, 385.

Bell, J. L., and Baron, D. N. (1959). Ibid., 12, 582.

Burch, H. B., Arroyave, G., Schwartz, R., Padilla, A. M., Béhar, M. Viteri, F., and Scrimshaw, N. S. (1957). J. clin. Invest., 36, 1579

Daly, J., and Jordan, A. (1959). L Lancet, 1, 256.

Dreyfus, J. C., Schapira, G., and Schapira, F. (1958). Ann. N.Y. Acad. Sci., 75, 235.

Edozien, J. C. (1958). W. Afr. med. J., n.s., 7, 121.

- (1959). Nature (Lond.), 184, 1150.

Hauss, W. H., and Leppelmann, H. J. (1958). Ann. N.Y. Acad. Sci. $75,250$.

Karmen, A. (1955). J. clin. Invest., 34, 131.

Kerppola, W., Nikkilä, E. A., and Pitkänen, E. (1959). Acta med. scand., 164, 357.

Powell, W. N. (1944), Amer. J. clin. Path., 14, Tech, sect. 8, 55.

Schwartz, R. (1956). J. clin. Path., 9, 333.

Shay, H., and Siplet, H. (1957). Gastroenterology, 32, 571.

Sperry, W. M., and Webb, M. (1950). J. biol. Chem., 187, 97.

Sterkel, R. L., Spencer, J. A., Wolfson, S. K., and Williams-Ashman H. G. (1958). J. Lab. clin. Med., 52, 176.

White, L. P. (1958). Ann. N.Y. Acad. Sci., 75, 349.

Wolfson, S. K., and Williams-Ashman, H. G. (1957). Proc. Soc. exp. Biol. (N.Y.), 96, 231.

Wolfson, W. Q., Cohn, C., Calvary, E., and Ichiba, F. (1948). Amer. J. clin. Path., 18, 723.

Wróblewski, F. (1958). Advanc. clin. Chem., 1, 313.

- and LaDue, J. S. (1956). Proc. Soc. exp. Biol. (N.Y.), 91, 569. 